\title{
Evaluation of hypoglicemic activity and healing of extract from amongst bark of "Quina do Cerrado" (Strychnos pseudoquina ST. HILL) ${ }^{1}$
}

\author{
Avaliação da atividade hipoglicemiante e cicatrizante de extrato da entrecasca da Quina do \\ Cerrado (Strychnos pseudoquina ST. HILL)
}

\author{
Adenilda Cristina Honório-França ${ }^{\mathrm{I}}$, Camila Moreira Ferreira Marinss", Fernando Boldrini" ${ }^{\mathrm{III}}$, Eduardo Luzía França ${ }^{\mathrm{IV}}$

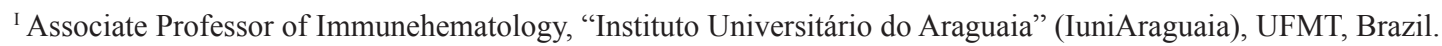 \\ II Graduate Student of Pharmacy/Clinical Analysis, "Instituto Universitário do Araguaia" (IuniAraguaia), UFMT, Mato Grosso, Brazil. \\ III Assistent Professor of Pharmacotecnic, "Instituto Universitário do Araguaia" (IuniAraguaia), UFMT, Mato Grosso, Brazil. \\ Iv Associate Professor of Cytopathology, "Instituto Universitário do Araguaia" (IuniAraguaia), UFMT, Mato Grosso, Brazil.
}

\begin{abstract}
Purpose: Evaluation the hypoglycemic and healing effects of the Strychnos pseudoquina. Methods: 33 Wistar rats were divided in the following groups, group 1 not sensitized with alloxan and untreated by aqueous extracts; group 2 sensitized with aloxana and untreated by aqueous extracts of Quina; group 3 sensitized by aloxana ad treated with the aqueous extract of quina. Diabetes was induced by alloxan diabetogenic drugs at a dose of $42 \mathrm{mg} / \mathrm{kg}$ of weight. The glycemias was evaluated by glycemic measuring Accu-check ${ }^{\circledR}$. To verify the healing, was made a longitudinal cut of $1 \mathrm{~cm}$ in the back of the mouse. The group 3 was treated with a microemulsion containing Strychnos pseudoquina. Wounds were macroscopically evaluated during pre-determined days after the cut $\left(1^{\text {st }}, 3^{\text {rd }}, 7^{\text {th }}, 9^{\text {th }}, 14^{\text {th }}\right)$. Results: The glycemia levels in the group treated with Strychnos pseudoquina were lower than the group sensitized by alloxan and not treated with Strychnos pseudoquina. There was no difference between the healing of the wounds treated with quina and another groups. Conclusions: Strychnos pseudoquina presents hypoglycemic effect. Meanwhile the topical use of the microemulsion of Strychnos pseudoquina presents no macroscopically significant effect on the healing of wounds in diabetic rats.
\end{abstract}

Key words: Diabetes Mellitus. Hypoglycemia. Wound Healing. Rats.

\section{RESUMO}

Objetivo: Avaliar o efeito hipoglicemiante e cicatrizante de Strychnos pseudoquina. Métodos: Utilizou-se 33 ratos Wistar, divididos nos seguintes grupos: grupo 1 não sensibilizado pela aloxana e não tratado pelo extrato aquoso; grupo 2 sensibilizado com aloxana e não tratado pelo extrato aquoso de Quina; grupo 3 sensibilizado pela aloxana, tratado com o extrato aquoso de Quina. O diabetes foi induzido pela aloxana, droga diabetôgenica, na dose de $42 \mathrm{mg} / \mathrm{Kg}$ de peso de rato. As glicemias foram avaliadas pelo medidor de glicemia Accu-check ${ }^{\circledR}$. Para verificar a cicatrização, foi realizado um corte de $1 \mathrm{~cm}$ longitudinal na região dorsal do rato, sob anestesia inalatória. O grupo 3 foi tratado com uma microemulsão contendo "Quina do Cerrado". As feridas foram avaliadas macroscopicamente nos períodos pré-determinados $\left(1^{\circ}, 3^{\circ}, 7^{\circ}, 9^{\circ}\right.$ e $14^{\circ}$ dias após o corte). Resultados: Os níveis glicêmicos do grupo com "Quina do Cerrado" foram menores que os do grupo sensibilizado pela aloxana e não tratados. Não houve diferença entre a cicatrização das feridas tratadas com Quina comparada à dos outros grupos. Conclusões: Strychnos pseudoquina apresenta efeito hipoglicemiante. Entretanto o seu uso tópico em microemulsão não apresenta efeito significativo na cicatrização de feridas em ratos diabéticos.

Descritores: Diabetes Mellitus. Hipoglicemia. Cicatrização de Feridas. Ratos.

${ }^{1}$ Research performed at Instituto Universitário do Médio Araguaia, Federal University of Mato Grosso (UFMT), Pontal do Araguaia - MT, Brazil.

\section{Introduction}

The diabetes is the most important condition which involves the endocrine pancreas, and one of the biggest causes of morbidity and mortality in the population. The prevalence is estimated in more than 150 million people with this disease in the world, and the brazilian adult population, that number comes to 12 million ${ }^{1}$.

It is a chronic disorder that interferes in the metabolism of carbohydrates, fats and proteins. An important aspect is the hyperglycemia in diabetes, which is a reflection of the deterioration in the utilization of glucose (carbohydrates) because of the poor response to secretion of insuline ${ }^{2}$.

Patients have greater susceptibility to serious infections due to several factors, including lower chemotaxis and phagocitic activity by neutrophils. These patients are more vulnerable to bacterial infections and consequent delays in the healing of wounds ${ }^{2}$.

Healing is characterized by a sequence of biological events, complex and dynamic to promote the repair of damage after an injury ${ }^{3,4}$. 
The microemulsions can be defined in general terms as transparent systems, thermodynamic stables and isotropics, obtained by mixtures of two liquids of different polarities (water and oil), containing a surfactant frequently associated with an appropriate cosurfactant, forming doplets or other structures with diameters in the order of $100 \mathrm{~nm}^{5}$.

The use of microemulsions as vehicle for pharmaceutical preparations has aroused great interest as systems for release of drugs because of potential advantages given ${ }^{6}$. These advantages are due to ability that they have to improve the solubility of substances hydrofilics and lypophilics, to increase stability and absorption of drugs dispersed, allowing greater bioavailability. Furthermore, the use of microemulsions can provide an sustained release of drugs because the compartmentalization these active substances, that means, their presence within structures organized by surfactants, water and oil, allowing a slow and continuing release of drug for a longer period of time ${ }^{5}$.

Since the older times, the man uses the plants as a source of medicines for the most diseases, including diabetes. Scientific research of medicinal plants can provide valorous evidence for the development of drugs to improve quality of life for chronic patients. The Brazilian Cerrado is rich in species that have therapeutic properties, among them is "Quina do Cerrado".

The "Quina do Cerrado", whose scientific name is Strychnos pseudoquina, belonging to the family Loganiaceae, it is a tree that reaches 3 to 6 meters in height, have thick bark, leaf oval, coriacea, fruit and rounded, hairless and yellow color. The genus Strychnos has history in popular medicine, where tea of that species is used against gastric disorders and the treatment of malaria ${ }^{7}$.

Despite the large popular employment, no article was found studying the hypoglycemic effect and scarring of "Quina do Cerrado". The aim of this work was to investigate the hypoglycemic effect and scarring of this plant in a model of experimental diabetes in rats. There is that the works are rare on use of Microemulsion in the evaluation of healing, or even to run for extracts or products of plant origin.

\section{Methods}

\section{Preparation of plant extract}

To obtain and drying of the plant material was collected to amongst bark of "Quina do Cerrado", put to dry in ventilated oven at $40^{\circ} \mathrm{C}$ for 7 days, until the complete drying. The botanical material was crushed by the state of powder, using a mortar and pestle, and a liquefier $\left(\right.$ Arno $\left.^{\circledR}\right)$.

The preparation of aqueous extract was through infusion with the powder, the extent of 200 grams of powder to $800 \mathrm{~mL}$ of distilled water. The water was boiled and evicted on the raw material, leaving to stand for twenty-five minutes. For oral administration, the aqueous extract was diluted in the proportion of $5 \mathrm{~mL}$ of aqueous extracts for each $995 \mathrm{~mL}$ of distilled water (Final concentration $=100 \mathrm{mg} / \mathrm{L})$.

To obtain the ethanolic extract were used $80 \mathrm{~g}$ of plant material. The plant was put in the cylindrical filter within Soxhlet extraction apparatus wich was coupled in a volumetric flask of $500 \mathrm{~mL}$ containing $250 \mathrm{~mL}$ of ethanol P.A. Then the Soxhlet apparatus and flask was connected to a condenser. It was used heating matle in the procedure extration of plant material, and the temperature was regulated below the boiling point of solvent. After this step, the ethanolic extract was concentrated in rotary evaporator (Quimis ${ }^{\circledR}$ ) at reduced pressure at a temperature of approximately $50^{\circ} \mathrm{C}$. Later the raw extract was placed at a temperature of $37^{\circ}$ to $38^{\circ} \mathrm{C}$ in oven to complete drying.

Soon after it was weigued $0,6 \mathrm{~g}$ of dry extract which was incorporated into $30 \mathrm{~g}$ of a microemulsion $\mathrm{W} / \mathrm{O}$ (water in oil) comprising $12 \%$ of soy lecithin, $18 \%$ of Eumulgin $B 2^{\circledR}$ (Cognis), $50 \%$ of Isopropyl Myristate and $20 \%$ of distilled water. The procedure was performed using mortar and pestle in ambient temperature.

\section{Samples}

It was utilized 33 Wistar rats, males and females, with average weight $200 \mathrm{~g}$. The animals were kept at room temperature and light/dark cycle, in wire-mesh cages, receiving feed and water ad libitum.

The experiment followed a protocol previously set by the search group, taking as standards of conduct the Helsinque Declation. The research project was evaluated institutionally and approved on the date form September 27, 2007.

\section{The experiment}

The rats were divided in 3 groups: Group 1 (G1) with $\mathrm{n}=11$, not sensitized and not treated with "Quina do Cerrado", the Group 2 (G2), with $n=11$, sensitized with alloxan and not treated with the extracts of "Quina do Cerrado", the Group 3 (G3), with $\mathrm{n}=11$, sensitized with alloxan and treated with solution of aqueous extract and with a microemulsion to $2 \%$ of "Quina do Cerrado".

The experimental protocol was 38 days, divided as follows: Adaptation period for 7 days; Treatment period with the aqueous extract of "Quina do Cerrado" for 7 days, diabetogenic period of 10 days and healing period for 14 days. In the period of adaptation the animals remained in individual cages and received water and feed ad libitum. During the period of treatment with the extract of the plant, the animals of $\mathrm{G} 3$ received $600 \mathrm{~mL}$ from aqueous extract of "Quina do Cerrado", and the volume of controlled daily intake. The others groups received $600 \mathrm{~mL}$ of water daily.

During diabetogenic period, the animals of the groups sensitized (G2 and G3) were kept without food for the preceding 12 hours, after that received intravenous injection of alloxan $\left(2,4,5,6\right.$-tetraoxypyrimidine; 5,6-dioxyuracil-Sigma $\left.{ }^{\circledR}\right)$ in the dose of $42 \mathrm{mg} / \mathrm{kg}$ of weight, in the median of the tail, in a single dose. On $3^{\text {rd }}$ day subsequent to the administration of alloxan, the glycemia levels were evaluated by measuring of glycemia Accu-chek ${ }^{\circledR}$ (Roche). The animals remained in cages for observation during 7 days, before starting the period of healing.

In the period of healing, the animals were subject to scraping of hair on the back in an area of approximately $4 \mathrm{~cm}^{2}$. Each animals was placed in closed glass container, containing cotton wool moistened with diethyl ether, to anesthesic induction, and were anesthetized by the immobility of the body, but with normal respiratory frequency and amplitude. Later was made a cut of $1 \mathrm{~cm}$ longitudinal in the back with a scalpel blade $\mathrm{n}^{\circ} 24$, with proper depth to keep within the subdermic region. Animals in G1 and G2 were treated with saline solution and animals in G3 treated 
with microemulsion to $2 \%$ of the "Quina do Cerrado". All animals were treated with $0,2 \mathrm{~mL}$ of products in cuts daily during the afternoon. The animals were evaluated in relation to the size and body weight and size of the cut to check the progress of healing on days $1^{\text {st }}, 3^{\text {rd }}, 7^{\text {th }}, 9^{\text {th }}$ and $14^{\text {th }}$ after the cut.

At the end of the sequence experimental, animals were anesthetized with diethyl ether, and then took place surgery, in all groups. The blood animals was collected before being sacrificed. Below the spleen, liver, right and left kidney, heart and lungs were removed for further evaluation biometric.

\section{Macroscopical evaluation}

In macroscopic analysis of wounds, were found the occurrence of hemorrhage, the presence and extent of crusts and extent of the wound. Evaluation by digital planimetry was done through of the wounds, all the animals had theis woundos photographed by digital camera model "Digimax 300", (Samsung $\left.{ }^{\circledR}\right), 3.2$ mega pixels, Zoom 3.0. and kept distance of approximately $34 \mathrm{~cm}$. The data thus obtained in the process of healing, in the $1^{\text {st }}, 3^{\text {rd }}, 7^{\text {th }}, 9^{\text {th }}$ and $14^{\text {th }}$ days, were recorded for later comparison.

\section{Statistical analysis}

The results were evaluated for healing through the program Bioestat version 2.0 by non parametric test of Kruskal-Wallis. To glycemic is used the analysis of variance (ANOVA). The statistics were considered significant when "p value" is less than $0,05(p<0.05)$. When $0.05<\mathrm{p}<0.10$ were considered the significance trend.

\section{Results}

\section{Glycemia levels evaluation}

It is observed that the glycemia levels decrease in the group were sensitized by alloxan and treated with aqueous solution of "Quina do Cerrado" (G3) when compared to the group sensitized by alloxan and not received the aqueous extracts of the plant (G2). The Glycemia levels of groups decreased gradually in the course of the experiment, however the values found on the G3 were approximately half of the values of G2 $(p<0.05)$ and similar to that of G1 (Figure 1).

\section{Macroscopical evaluation}

The macroscopic data showed complete healing after 14 days of the cut in all groups (Figures 2, 3 and 4). The evolution of healing wound in rats of both groups showed crusts sensitive to the 7-day after cutting. From the 7-day, there was improvement and development for epithelization to $14^{\text {th }}$ day, but there has been significant growth of hair around the injury.

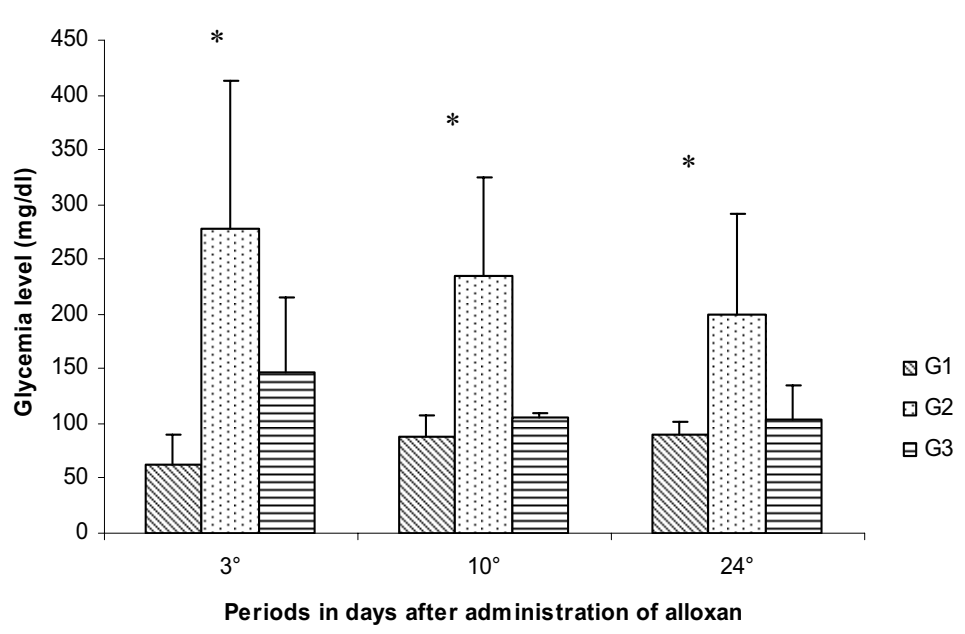

FIGURE 1 - Glycemia level (mg/dl) evaluation during 24 days in the rats sensitized or not with alloxan and treated or not with the extracts of "Quina do Cerrado".

The results represent the mean \pm SD of 11 animals each group $* \mathrm{p}<0.05$ comparing the treatead groups with alloxan with the group untreated group, considering the same days.

A

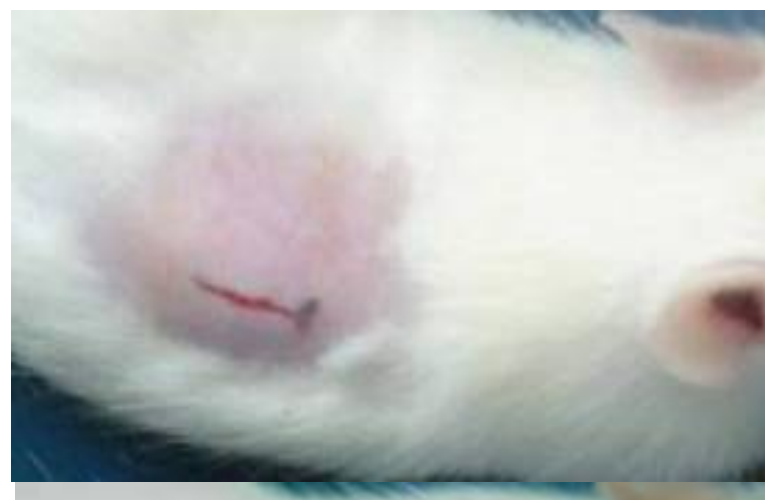

B

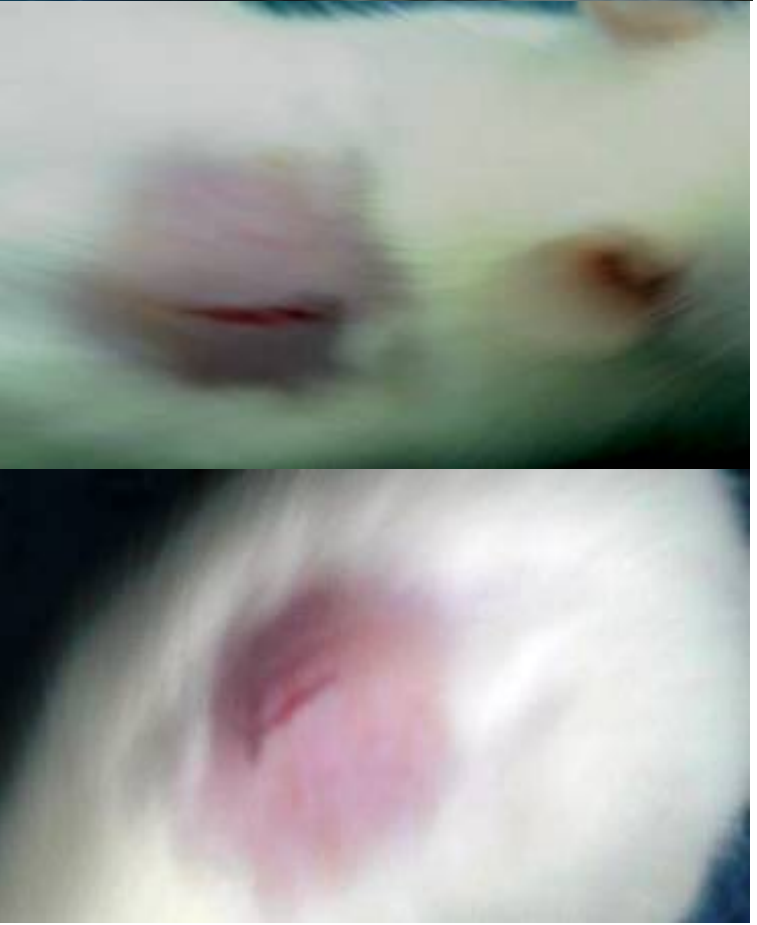

FIGURE 2 - Macroscopical evaluation of $1^{\text {st }}(A), 7^{\text {th }}(B)$ e $14^{\text {th }}($ C) days after the cut, showed the wound area in the rats not sensitized with alloxan and not treated with the extracts of "Quina do Cerrado" (G1) 
A

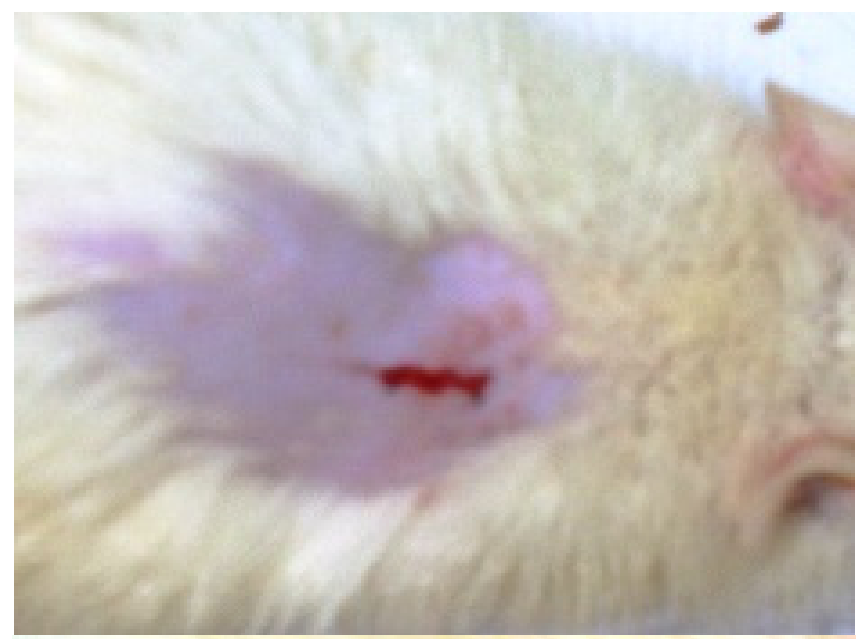

B

$\mathrm{C}$

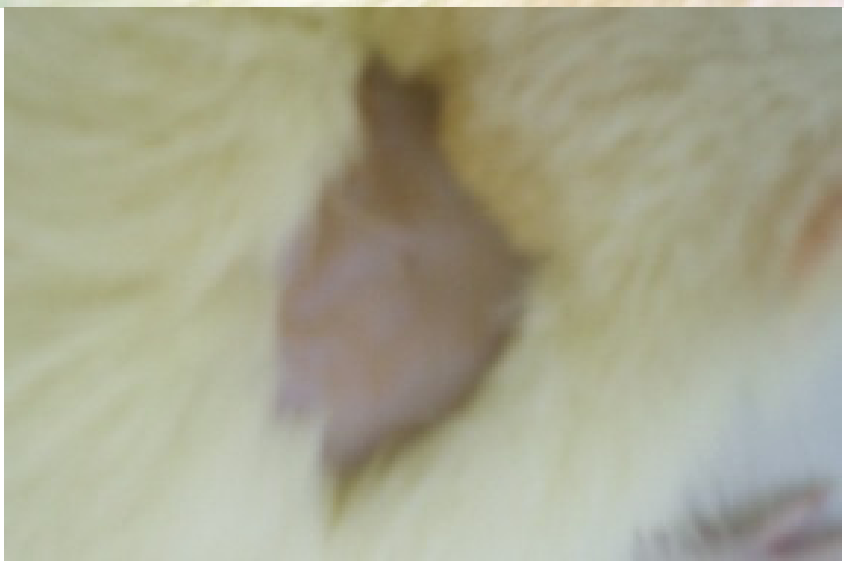

FIGURE 3 - Macroscopical evaluation of $1^{\text {st }}(\mathrm{A}), 7^{\text {th }}(\mathrm{B})$ e $14^{\text {th }}(\mathrm{C})$ days after the cut, showed the wound area in the rats sensitized with alloxan and not treated with the extracts of "Quina do Cerrado" (G2)

\section{Evaluation of the wound area}

Analysis of healing with the evolution of time showed that the size of the wounds decreased gradually (Figure 5).

When compared to the evolution of wounds in the group non-diabetic and diabetic group, no significant difference was found in the average size of the scar between groups in moments evaluated. When the groups were compared with each other, the average size of the scar similar.

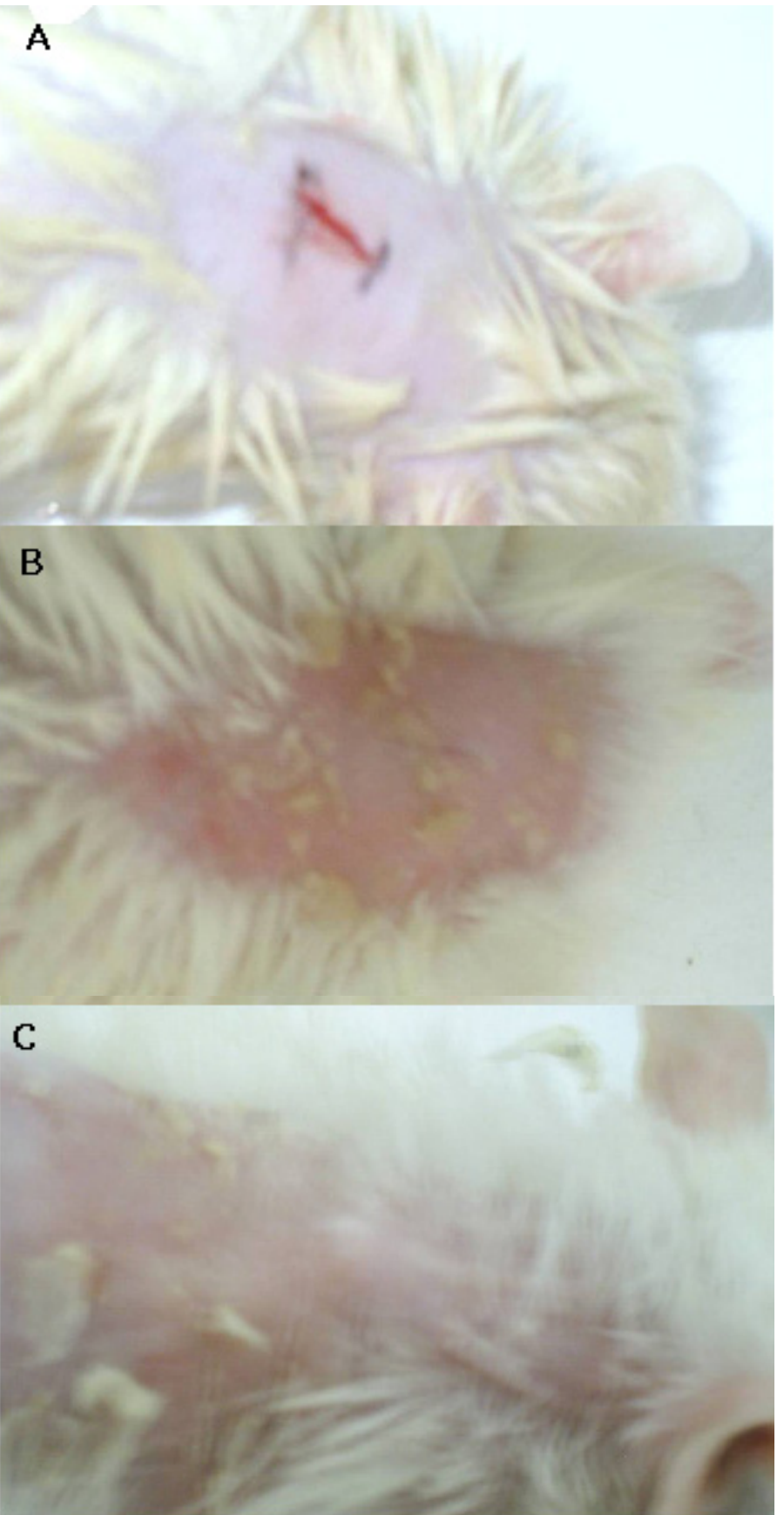

FIGURE 4 - Macroscopical evaluation of $1^{\text {st }}(\mathrm{A}), 7^{\text {th }}(\mathrm{B})$ e $14^{\text {th }}(\mathrm{C})$ days after the cut, showed the wound area in the rats sensitized with alloxan and treated with the extracts of "Quina do Cerrado" (G3)

\section{Evaluation of biometrics}

The comparison between the average weights of the organs, presented significant differences in the heart and lungs of animals that were treated with aqueous extracts of "Quina do Cerrado" (Figure 6). The variance was found in the lung $(p=0.05)$ showing a trend to significance and in the hearts this variation was significant $(p=0.04)$. 


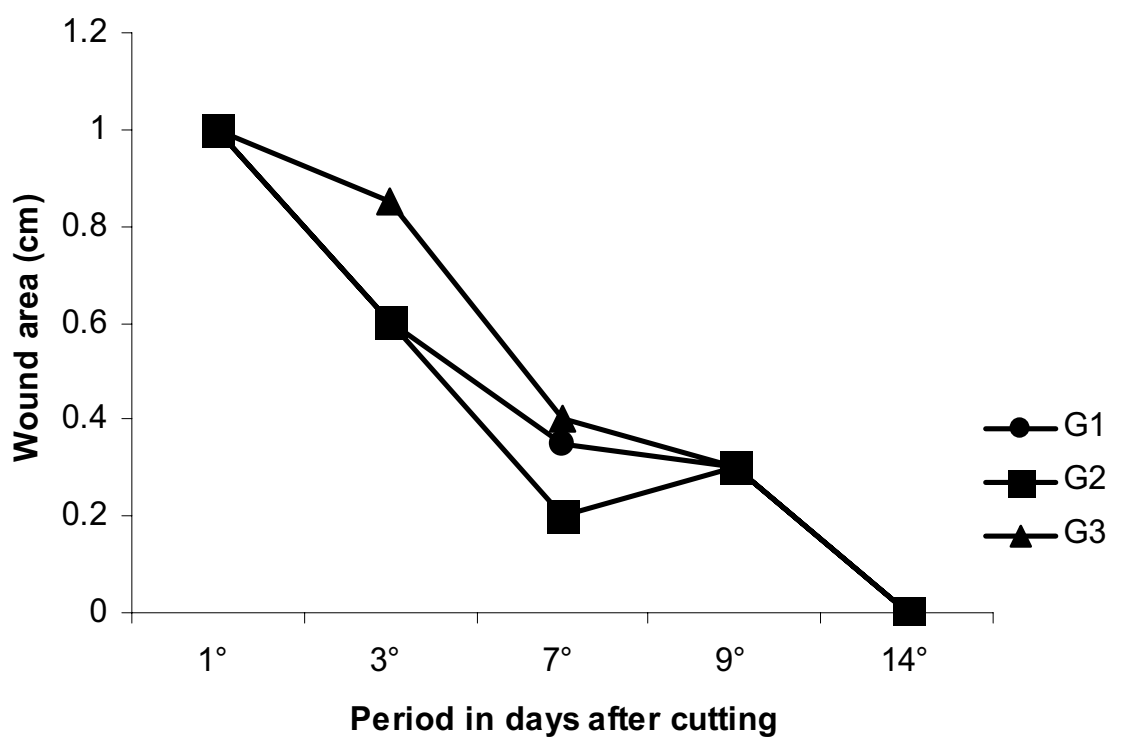

FIGURE 5 - Wound area $(\mathrm{cm})$ evaluation during 14 days after cutting in the rats sensitized or not with alloxan and treated or not with the extracts of "Quina do Cerrado". The results represent the mean \pm SD of 11 animals each group

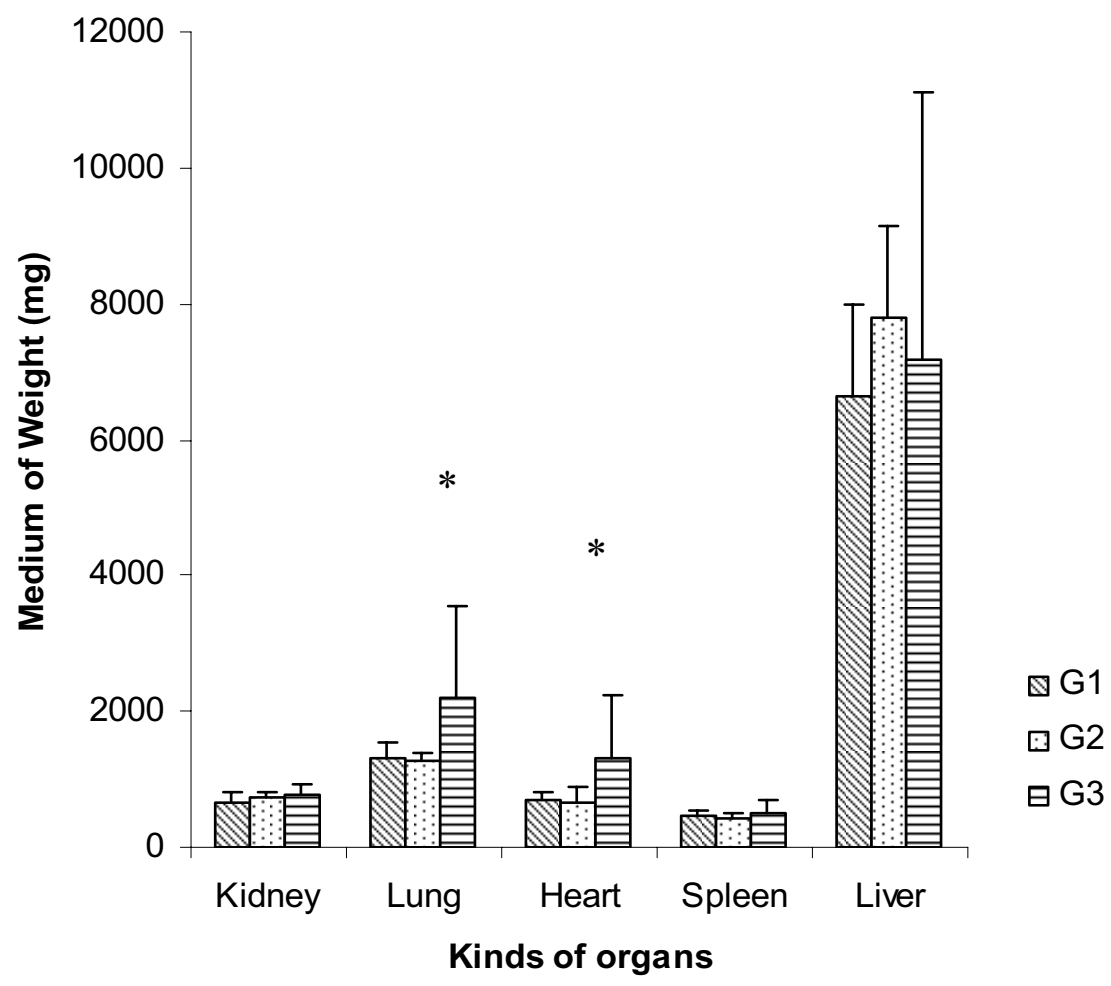

FIGURE 6 - Evaluation of biometrics in the rats sensitized or not with alloxan and treated or not with the extracts of "Quina do Cerrado". The results represent the mean \pm SD of weight different organs of 11 animals each group

${ }^{*} \mathrm{p} \leq 0.05$ comparing the treated groups with alloxan with the group untreated group, considering the same organ. 


\section{Discussion}

Diabetes mellitus is considered a major public health problem in both developed and developing countries due to its chronic complications, at the macro or microcirculation, with great impact on mortality and morbidity in all patients. The disease is considered the end of a pathophysiologic. The World Health Organization estimates that $80 \%$ of the population of developing countries in the world use medicinal plants as medicines. They may be in the form of teas, juices, salads, dyeing, soups, bathing, cataplasm, gargles, inhalations, washes, ointments, unguent and oils ${ }^{8}$.

The "Quina do Cerrado", belonging to the group Strychnos, is a plant much used as medicine ${ }^{7}$. Studies indicate the popular knowledge about the use of "Quina do Cerrado", and the amongst bark pulverized in the form of tea as scarring, antidiarrheal disease, antimicrobial and muscle relaxant, depressant of central nervous system, sedating and hypotensive?

In this study, rats were used as the experimental animals, to have advantages over animals for greater port because of the ease of handling and accommodation, resistance to manipulation, to infections and tolerance to surgery, besides submitting similarities clinical, laboratory and histopathology with the human diabetes ${ }^{9}$.

The experimental diabetes can be induced in animals by chemical mechanism beta-cytotoxic, as the alloxan and streptozotocin, the chemical agent chosen in this study was the alloxan, by using widely disseminated in the production of experimental diabetes. The drug remains 10 minutes in the circulation and cause permanent damage leading to the pancreas beta-cells, during the early hours, a triphasic in glycemia levels, with subsequent establishment of diabetes in 24 hours, so this study was the first glycemic evaluated three days after the induction with alloxan'.

An important aspect to be considered is the route of administration of drug alloxan. The intravenously is where the effects are most evident and have been the choice of most animal species ${ }^{9}$.

The effects in glycemia levels on rats with diabettes alloxan induced treated with infusion of Bauhinia candicans or Syzygium jambolanum were studied and it was found that the plant $S$. Jambolanum was effective in reducing hyperglycemia, as a $B$. Candicans has no effect on hyperglycemia ${ }^{10}$.

The hypothesis to explain the decrease in blood glucose in this study probably due to the action of substances present in "Quina do Cerrado", so there are several studies that show substances extracted from plants that reduce the level of glucose in the blood ${ }^{11}$

The Diabetes has been constantly linked to the difficulty of healing of wounds. This causes increased risk of infections due to the cellular changes that cause the low synthesis of collagen ${ }^{1}$.

Studies indicate that in rats with diabetes induced by drug alloxan produce less of granulation tissue that normal rats ${ }^{1}$. In the present study there was no significant difference between the macroscopic evolution of the wounds of diabetic rats and non-diabetics, with $p>0.05$, but reported in the literature is the difference microscopic to this development. The scars on animals with induced diabetes show low resistance, caused by deficiency of insulin, which should be attributed to biochemical changes in the area of the wound ${ }^{1}$.
The region chosen to produce the wound was the dorsal and had intended to prevent the animal itself could reach it to be experimental model of wound well known ${ }^{12}$.

It should be also considered the use of microemulsion in this experiment. There are a number of biological barriers between the application site and the place where substances should exert their pharmacological effect, so many pharmacologically active substances fail to achieve the appropriate concentration in the target tissue and expose the normal tissues of the body to the effects of potentially toxic substances. The skin is a biological barrier, which allows the passage of substances under certain conditions. The microemulsions may interact with the stratum corneum disorganizing the lipid bilayer of the skin due to surfactants. Thus, these lipids pass for a more fluid and disorderly, increasing the permeability skin and penetration of substances is quite easy. It is important to note that the control of the release, mediated by microemulsions, it is an important advantage when it seeks specific targets and extension of the therapeutic action, which would be important for healing wounds of difficult and in diabetes ${ }^{5}$.

Morphological and morphometrical aspects of the development scarring of skin wounds in back of rats treated with aqueous solution of Stryphynodendron barbatiman martius were studied, and the results showed that this solution significantly helped in the repair of skin wounds in mice ${ }^{13}$.

The influence of the extract of Passiflora edulis in the healing of opened skin wounds in rats was searched and the results showed that the topical use of the extract of Passiflora edulis no significant macroscopically effect on healing of wounds in the skin of mice; however microscopically presented increasing proliferation fibroblastic in the $7^{\text {th }}$ day and greater collagen on the $14^{\text {th }}$ day of post-operatively ${ }^{12}$.

The evaluation of the hydroalcoholic extract of Schinus terebinthifolius Raddi in the healing process of wounds skin in rats was studied and the results showed that the extract delayed the reepitelization of the skin wounds in rats ${ }^{3}$.

A wound is isolated from the environment after it is completed by clots, fibrinas and exudates, forming a crust. During the study, there was no episode of bleeding and secretions. In the first period of observation, to the 7-day-evaluation after the completion of the cut, there was formation of the crust wounds in both groups; it was noted by several authors ${ }^{3,12}$.

The size of the wound evolved with gradual decrease, with no significant difference between the groups assessed, it was observed by Garros ${ }^{12}$.

In the presence of diabetes occur in the control problems and cardiovascular function. Primary changes are observed (around 5 days) in blood pressure controlled by different receptors peripherals that are kept for several months after the induction of diabetes. One of the different mechanisms of cardiovascular control is the activation of cardiopulmonary reflex for a stimulant found in different structures of the chest, including atrium, ventricle, veins, and pulmonary parenchyma, which represents an important source of information on changes in volume and blood pressure of region cardiopulmonary ${ }^{14}$.

Research conducted with the kind Strychnos pseudoquina indicate the presence of alkaloids nor-dihydroxytoxiferine, diaboline and 11-methoxydiaboline, isolated from the bark of the root, the trunk and branches. The substance diaboline can stop 
breathing and cause hypotension, and the substance nor-dihydroxytoxiferine has owned sedating and relaxing nervous system central ${ }^{7}$, which may explain the difference between the average weight of the heart and lung found in the experiment of healing.

\section{Conclusion}

The use of "Quina do Cerrado" presents hypoglycemic effect. Meanwhile the topical use of the microemulsion containing extract of Strychnos pseudoquina presents no macroscopically significant effect on the healing of wounds in diabetic rats.

\section{References}

1. Carvalho PTC, Mazzer N, Reis FA, Belchior ACG, Silva IS. Analysis of the influence of low-power HeNe laser on the healing of skin wounds in diabetic and non-diabetic rats. Acta Cir Bras. 2006;21:177-83.

2. Rocha JLL, Baggio HCC, da Cunha CA, Niclewicz EA, Leite SAO, Baptista MIDK. Aspectos relevantes da interface entre diabetes mellitus e infecção. Arq Bras Endocrinol Metab. 2002;46:221-9.

3. Branco-Neto MLC, Ribas-Filho JM, Malafaia O, Oliveira-Filho MA, Czeczko NG, Aoki S, Cunha R, Fonseca VR, Teixeira HM, Aguiar LRF. Avaliação do extrato hidroalcoólico de Aroeira (Schinus terebinthifolius Raddi) no processo de cicatrização de feridas em pele de ratos. Acta Cir Bras. 2006;(Suppl 2):17-22.

4. Modolin M, Bevilacqua RG, Ruy G. Cicatrização das feridas. Síntese das aquisições recentes. Rev Bras Clin Terap. 1985;14(6):208-13.

5. Lawrence MJ, Rees GD. Microemulsion-based media as novel drug delivery sustems. Adv Drug Deliv Rev. 2000;45:89-121.
6. Júnior ASC, Fialho SL, Carneiro LB, Oréfice F. Microemulsões como veículo de drogas para administração ocular tópica. Arq Bras Oftalmol. 2003;66:385-91.

7. Silva MA, Souza-Brito ARM, Hiruma-Lima CA, Santos LC, Sannomiya M, Vilegas W. Strychnos L. da América do Sul e Central. Rev Bras Farmacogn. 2005; 15:256-67.

8. Teixeira CC, Fuchs FD. The efficacy of herbal medicines in clinical models: the case of Jambolan. J Ethnopharmacol. 2006;108:16-9.

9. Lerco MM, Spadella CT, Machado JLM, Schellini SA, Padovani CR. Caracterização de um modelo experimental de Diabetes mellitus, induzido pela aloxana em ratos: estudo clínico e laboratorial. Acta Cir Bras. 2003;18(2):132-42.

10. Soares JCM, Costa ST, Cecim M. Níveis glicêmicos e de colesterol em ratos com Diabetes Mellitus aloxano induzido, tratados com infusão de Bauhinia candicans ou Syzygium Jambolanum. Cienc Rural. 2000;30:113-8.

11. Negri, G. Diabetes melito: plantas e princípios ativos naturais hipoglicemiantes. Rev Bras Cienc Farm. 2005;41:121-42.

12. Garros IC, Campos ACL, Tâmbara EM, Tenório SB, Torres OJM, Agulham MA, Araújo ACF, Sains-Isolan PMB, Oliveira EM, Arruda ECM. Extrato de Passiflora edulis na cicatrização de feridas cutâneas abertas em ratos: estudo morfológico e histológico. Acta Cir Bras. 2006;21(Supl 3):55-65.

13. Eurides D, Mazzanti A, Belleti ME, Silva LAF, Fioravant MCS, Neto NST, Campos VA, Lemos RC, Junior PLS. Morfometria e morfologia da reparação tecidual de feridas cutâneas de camundongos tratadas com solução aquosa de barbatimão (Stryphynodendron barbatiman martius). Rev Fac Zootec Vet Agro. 1996;3:35-40.

14. Angelis K, Schaan BD, Maeda CY, Dall'Ago P, Wichi RB, Irigoyen MC. Cardiovascular control in experimental diabetes. Bras J Med Biol Res. 2002;35(9):1091-100.

Conflict of interest: none Financial source: none

\section{Correspondence:}

Dr.Eduardo Luzía França

Instituto Universitário do Araguaia - UFMT

Rodovia MT100, Km 3,5 s/no

78698-000 Pontal do Araguaia - MT Brazil

elfranca@ufmt.br

Received: May 14, 2008

Review: July 15, 2008

Accepted: August 14, 2008

\section{How to cite this article}

Honório-França AC, Marins CMF, Boldrini F, França EL. Evaluation of hypoglicemic activity and healing of extract from amongst bark of "Quina do Cerrado" (Strychnos pseudoquina ST. HILL). Acta Cir Bras. [serial on the Internet] 2008 Nov-Dec;23(6). Available from URL: http://www.scielo.br/acb

*Color figures available from www.scielo.br/acb 